\title{
6. Afterlives of the Apparatus
}

\begin{abstract}
In this chapter, the focus lies on the "afterlives" of Cahiers du cinéma's post1968 period in Anglo-American film studies since the latter's consolidation as an academic discipline in the 1970s. Championed by journals such as Screen, the writings of the Cahiers critics attained a wide purchase in the nascent field, but this often came at the expense of a reductive interpretation, compounded by the limited corpus of available translated texts, and in later decades many of the positions associated with Cahiers increasingly came under attack, while even its defenders admitted to the state of crisis that the "political modernism" it represented had entered. But this chapter also shows the wider influences that Cahiers has had on film scholarship, such as the importance of Comolli for the rise of the "new film history" movement, and it concludes by stressing the necessity for a productive re-reading of the original Cahiers texts.
\end{abstract}

Keywords: Cahiers du cinéma, Screen, political modernism, apparatus theory, feminist film theory, new film history

\section{Cahiers du cinéma and "Screen Theory"}

A discussion of the role played by theories of ideology and the cinematic apparatus in the Cahiers of the post-1968 period would not be complete without examining the effects they have had on film theory and on AngloAmerican academic film studies in particular. These effects, in spite of the period of relative neglect they have suffered since the 1980s, continue to leave their marks on the field up to the present day. This chapter will therefore center on the "afterlives" of the theoretical texts of Cahiers in the English-speaking world, a phenomenon that is every bit as tumultuous as the history of the journal itself.

It was the UK journal Screen that initially played the role of introducing the work of the Cahiers writers to English-speaking readers in the early 1970s,

Fairfax, D., The Red Years of Cahiers du Cinéma (1968-1973). Volume I: Ideology and Politics. Amsterdam: Amsterdam University Press, 2021 DOI 10.5117/9789463728508_CHo6 
and these texts were used as a springboard for a burst of original work that viewed the cinema through the prism of radical aesthetics, psychoanalytic theory and, later, feminist accounts of spectatorship. But the Cahiers writers would find themselves under attack as "1970s theory" was subject to withering critiques in the 1980 s from several angles, including, most notably, the positivist "post-theory" of figures such as Noël Carroll and David Bordwell. This offensive has left Cahiers inhabiting a curious position within the discipline. A limited number of its texts have unmistakably passed into the film studies canon and remain required reading for those entering the field. For the most part, however, they are seen chiefly as genealogical precursors to the efforts of the Screen theorists and other pioneering scholars in the field rather than theoretical contributions in their own right, inscribed into a critical lineage distinct from that of Anglo-American film theory.

Screen had very different origins to Cahiers, beginning life as a pedagogically oriented quarterly under the auspices of the British Film Institute rather than an independent monthly magazine targeted at a broad, non-academic readership. Moreover, once its politically radical phase had dissipated in the 1980s, Screen was transformed into a standard scholarly journal-a function it still plays today but a path that was never taken by its French counterpart. For much of the 1970s, however, Screen adopted a theoretical and political orientation broadly analogous to that of Cahiers in the 1968-1973 period. Discussions of the theoretical evolution of Screen are abundant and can easily be found elsewhere. ${ }^{1}$ Here I will restrict myself to the ramifications of its exposure to the key ideas articulated by Cahiers.

Screen's very transformation, in 1971, to a journal preoccupied with theories of the cinema inspired by Althusserian Marxism and Lacanian psychoanalysis occurred on the basis of contemporaneous developments in French film theory and more particularly the evolution of Cahiers. It is indicative here that the first issue of the "new" Screen (vol.12 no. 1), under Sam Rohdie's editorship, contained a translation of "Cinéma/idéologie/critique" along with a pair of explicatory articles on the status of contemporary French film criticism. ${ }^{2}$ This acknowledgement of the importance of Cahiers for the English journal was continued in vol. 12 no. 3 with the publication of

1 See, in particular, Rodowick, The Crisis of Political Modernism; and Philip Rosen, "The Concept of Ideology and Contemporary Film Criticism," PhD dissertation, University of Iowa, 1978. For a more personal account of this period, see Colin MacCabe, Tracking the Signifier: Theoretical Essays: Film, Linguistics, Literature (Minneapolis: University of Minnesota Press, 1986).

2 See Jean-Luc Comolli and Paul Narboni [sic], "Cinema/Ideology/Criticism (1)"; Claire Johnston, "Film Journals: Britain and France," Screen vol. 12 no. 1 (Spring 1971), pp. 39-48; and Ben Brewster, "Structuralism in Film Criticism," Screen vol. 12 no. 1 (Spring 1971), pp. 49-58. 
Cinéthique's ripostes to its rival ("Direction" by Gérard Leblanc and "La parenthèse ou le détour" by Jean-Paul Fargier) as well as part II of Cahiers' editorial. English versions of these texts were produced by a BFI-funded translation project closely linked to Screen, which proved crucial to the development of film studies in the anglophone world during this period. ${ }^{3}$ While this endeavor also involved translations of German, Italian and Russian texts relating to twentieth-century radical art, the French articles formed the focal point of the project. This undertaking allowed for key Cahiers texts such as "Young Mr. Lincoln de John Ford" and Oudart's "La Suture" to appear in translated form in Screen during this period, while others (including "Technique et idéologie"), although never officially published by Screen, were translated and distributed through informal channels on the back of the BFI project. ${ }^{4}$

Screen never sought, however, to operate a direct transposition of Cahiers' ideas in a British environment. Rather, it was a theoretically syncretic endeavor, outlining the basis of a political aesthetics of the cinema that drew from both Cahiers and Cinéthique (and tended to stress the similarities between the two journals rather than their differences), as well as Metz, Althusser, the Russian formalists and Brecht. Although many of these influences were shared with the French journal, subtle differences in emphasis and orientation can be discerned: the British quarterly, for instance, placed a much greater emphasis on Brecht's praxis of distantiation (Verfremdung) than Cahiers, for whom the German playwright would only gain prominence in the years 1972-1973. ${ }^{5}$ As with Cahiers, Godard, Straub/Huillet and Oshima were held up as models of contemporary political cinema, while the importance of 1920 S Soviet cinema as a historical case study was underscored. But Screen also entertained a much greater interest in anti-fascist and popular front filmmaking from the 1930s and 1940s, which was of only passing concern for Cahiers, and, betraying its institutional origins in the pedagogical arm of the BFI (an affiliation that was maintained even at the

3 One of the key translators, Diana Matias, was also an editorial assistant for Screen between 1970 and 1972.

4 The first installment of "Technique et idéologie" was eventually formally published in the short-lived American journal Film Reader in 1977. See Jean-Louis Comolli, "Technique and Ideology: Camera, Perspective, Depth of Field," trans. Diana Matias, Film Reader no. 2 (1977), pp. 128-140. Parts III and IV were published, in a modification of Matias' translation by Marcia Butzel and Philip Rosen, in Rosen (ed.), Narrative, Apparatus, Ideology, pp. 421-443. The entirety of "Technique et idéologie" was published in English for the first time, in a new translation, in 2015, as part of Comolli, Cinema against Spectacle, pp. 143-244.

5 Cahiers did exhibit some interest in Brecht in the early 1960 , resulting in a dossier on the dramatist assembled by Bernard Dort in the December 1960 issue. 
height of its "Freudo-Marxist" phase), Screen displayed more interest in the public reception of films, contrasting with Cahiers' blithe indifference to the question of the cinema audience. Moreover, Screen tended towards a more binary antithesis between "classical realism" and "modernism" in the cinema, whereas Cahiers evinced more of a fascination for the internal contradictions of Hollywood filmmaking. Although the "Young Mr. Lincoln" article was republished and discussed at length in Screen, there was a paucity of parallel attempts made under the auspices of the English journal, with Stephen Heath's analysis of Touch of Evil constituting a significant exception.

Differences emerged in other areas: Screen was more dismissive of the work of Bazin, who was viewed as merely representing an "idealist" approach to the cinema, ${ }^{6}$ whereas-as the governing hypothesis of this book maintains - the Cahiers of the post-1968 period continued to be exercised by its founder's ideas. In this sense, then, Screen hewed more closely to Cinéthique than Cahiers, and such an inclination can also be seen in the journals' respective approaches to ideology and cinema. Although the work of Cahiers in this area was repeatedly highlighted by Screen, writers such as Colin MacCabe and Ben Brewster tended to conceive of the cinema as an illusionist apparatus serving primarily to occlude the real nature of social relations. Finally, Screen tended towards an ascetic, even puritanical attitude towards the cinema. In articles including "Visual Pleasure and Narrative Cinema" by Laura Mulvey and "Principles of Realism and Pleasure" by Colin MacCabe, ${ }^{7}$ spectatorial pleasure came largely to be seen as a pernicious instrument of bourgeois cinema; instead, the viewer was urged to "work" to understand a film such as Straub/Huillet's Geschichtsunterricht. ${ }^{8}$ Indeed, the notion of "work" as it appeared in Screen tended to be an overly literal understanding of the word (as productive labor or toil), in contrast to the use made by Cahiers of the term travail, which followed Kristeva in referring more broadly to processes of textual transformation (in like fashion to Freud's concept of the "dream-work"). Spectatorial pleasure, it must be stressed, was never fully rejected by the

6 See, for instance, Christopher Williams, "Bazin on Neo-Realism," Screen vol. 15 no. 1 (Spring 1974), pp. 61-68, and Peter Wollen's more theoretically fertile contribution “'Ontology' and 'Materialism' in Film," Screen vol. 17 no. 1 (Spring 1976), pp. 7-25.

7 Laura Mulvey, "Visual Pleasure and Narrative Cinema," Screen vol. 16 no. 3 (Autumn 1975), pp. 6-18; and Colin MacCabe, "Principles of Realism and Pleasure, Screen vol. 17 no. 3 (Autumn 1976), pp. 7-27.

8 See, for instance, the discussion between Martin Walsh and Colin MacCabe in "The Politics of Separation (on Deux ou trois choses que je sais d'elle and Tout va bien)," Screen vol. 16 no. 4 (Winter 1975), pp. 46-61, here pp. 59-6o. 
Cahiers writers, who were reluctant to purge themselves of their cinephilic backgrounds. Far from understanding a film such as Othon as forestalling the possibility of aesthetic pleasure, the Cahiers critics explicitly took the opposite stance. In an interview with Politique-Hebdo, they declared it to be a "beautiful" and "pleasurable" film:

Let us once again clarify: all this in no way means that we have "elected" this film for its "inaudibility," its "hermeticism," its rebarbative, provocative character. On the contrary, we feel that Othon is a very beautiful film, also capable of arousing pleasure, but a pleasure which, let us be clear, has nothing to do with the narcissistic identification and hedonism which is almost always the rule in cinematic spectacle. ${ }^{9}$

The initial importation of Cahiers' ideas into the English-speaking world, by means of the work carried out primarily by Screen, is thus a transposition marked by a certain number of "translation issues." This applies on a broader level — the appropriation of theoretical concepts in a markedly different political and cultural environment could not take place without certain effects of distortion, assimilation and reduction - but was also, to a certain degree, exacerbated by translation issues in the narrower sense. Not all the writers for Screen - let alone its readers - were conversant in French, and they were thus reliant on the BFI translation project for exposure to original texts written by Cahiers, Cinéthique and others. While these translations were of crucial importance for disseminating the key ideas espoused by the French journals and have since achieved a canonical status through recurrent inclusion in film theory anthologies, they nonetheless tended to have a reductive effect on the reception of Cahiers in the English-speaking world. Through this process, the voluminous, theoretically paroxysmal output of the late 1960 s and early 1970 s was winnowed down to a handful of programmatic texts that were constituted into a more easily digestible "line." Even those articles that were translated were often rendered into English in a hasty fashion by translators who were not always familiar with the theoretical context of the original texts. The most egregious example here is Bennett's rendering of "Cinéma/idéologie/critique," some of whose infelicities have already been discussed above. Rodowick has recently maintained that, "in retrospect, this translation seems tendentious in a way that smooths out the style of the text to make it seem more formal and 
'scientific,"'10 and similar tendencies can be discerned in other translations published by Screen, including those of the prominent texts "Technique et idéologie," "La Suture" and "Young Mr. Lincoln."

\section{Lines of Flight: Radical Politics, Psychoanalysis and Feminist Theory in the 1970 s}

A certain level of distortion thus occurred when the ideas initially developed by Cahiers were imported to the English-speaking world, and these continued to be present during the solidification of what has come to be known as "Screen theory," "1970s theory" or (pejoratively) "Grand Theory" into a recognizable theoretical paradigm. The positive aspect of this phenomenon, however, was the re-thinking of some of the key concepts of "apparatus theory" and their application in new and often strikingly different social and ideological contexts. The "field" of film theory was considerably expanded by this process, which took place not only on the pages of Screen but also in journals such as Afterimage, Wide Angle, Ciné-tracts, Monogram and Jump Cut. Three "lines of flight" produced by the migration of concepts from France to the UK and North America are particularly worth discussing: the encounter of film theory with far-left politics at a time of student and worker radicalization in the English-speaking world, the recasting of psychoanalytic theories of film spectatorship, and the advent of feminist theories of the cinema. While the former two areas entailed re-working aspects of film theory already explored at great length by Cahiers, a feminist approach to the cinema was mostly absent from the French journal's considerations during this period and would only-belatedly-be broached in the second half of the 1970 s by later contributors such as Thérèse Giraud, Nathalie Heinich and Danièle Dubroux. Cahiers was not alone in this neglect: if anything, other French film journals were even more masculinist in their outlook. In this case, then, Anglo-American film theory represented a crucially important advance on its French sibling.

While on a broader social level, the scale of political radicalization was an order of magnitude lower in the US and the UK than it was in France, film culture was profoundly affected by the rise of the "new left" in these countries, and this was reflected both in the birth of new, explicitly political film periodicals and the transformation of existing outlets. While publications such as Screen and Wide Angle (a US-based quarterly founded in 
1976), focused more on theoretical and historical questions rather than interventions into the political arena, magazines such as Afterimage in the UK and Ciné-Tracts in Canada were more concretely engaged with contemporary issues and sought to articulate them with the radical filmmaking of the day. ${ }^{11}$ In both publications, the films of the Groupe Dziga Vertov were of primordial importance, with Third Cinema, militant films and the work of the experimental avant-gardes also given attention. For an articulation of the theoretical legacy of Cahiers with far-left politics in the anglophone context, however, the most interesting organ was the American film review Jump Cut, edited by Chuck Kleinhans and Julia Lesage. Familiar with the political milieu in which Cahiers was operating (the two traveled to Avignon for the 1972 symposium organized by the Cahiers editors ${ }^{12}$ ), the Jump Cut editors were nonetheless critical of many aspects of apparatus theory as developed by Cahiers. This ambivalence was shown in Jump Cut's April 1978 issue: here, Kleinhans came to the defense of the French journal when responding to a more unambiguously negative article on Cahiers by William Guynn, who had lacerated the journal by equating its work with "the crude ideology and class-determinism of Socialist Realism." ${ }^{\text {"13 }}$ At the same time, Kleinhans insisted on the need for "a political critique of Cahiers," which, in his view, is "studiously evaded by most of those who profess the importance of recent French film thought and filmmaking." ${ }^{\prime 14}$ While this critique is never explicitly produced on the pages of Jump Cut, it can be read en creux in a large number of articles in the journal responding to militant and avant-garde filmmaking throughout the 197os.

If Jump Cut did not issue a thoroughgoing critique of Cahiers, its editors nonetheless assailed the psychoanalytic approach to cinema developed by Cahiers critics such as Oudart, Bonitzer and Pierre Baudry, as well as, subsequently, by writers associated with Screen. A concern for psychoanalytic theory postdated Screen's Marxist turn. It was not until the Summer 1974 issue of Screen that film was discussed in conjunction with psychoanalysis in any prolonged fashion, following on from cursory remarks made in the previous issue's editorial. In both cases, however, the links forged were

11 Afterimage was established by Simon Field and Peter Sainsbury at the University of Essex and published intermittently between 1970 and 1987. For a brief, first-hand account of its history, see Simon Field (with Peter Sainsbury), "Présentation," in Nicole Brenez and Michael Witt (eds.), Jean-Luc Godard: Documents (Paris: Centre Pompidou, 2006), p. 144.

12 Chuck Kleinhans, private communication, March 22, 2016.

13 William Guynn, "The Political Program of Cahiers du cinéma, 1969-1977," Jump Cut no. 17 (April 1978), pp. 32-35, here p. 32.

14 Chuck Kleinhans, "Twelve Frames per Second," Jump Cut no. 17 (April 1978), p. 36. 
highly idiosyncratic: the Spring 1974 editorial read Barthes' S/Z through a Freudian lens, while texts by MacCabe and Heath sought to do much the same for Brechtian aesthetic practice by drawing on the concept of fetishism..$^{15}$ This perspective was opposed from a feminist standpoint by Lesage in Jump Cut, but her rebukes of the Screen writers in this text are too scattered to constitute a sustained critique. ${ }^{16}$ Reprinted in Screen, her article was vigorously rebutted in a rejoinder authored by Brewster, MacCabe and Heath, who defended their use of psychoanalytic concepts in film theory but insisted that they did so at a remove from "a monolithic 'orthodox Freudianism'" that was in any case far less preponderant in the British context than it was in the United States. The three also sought to draw links between Freud and the contemporary theoretical work of Althusser and Barthes. ${ }^{17}$ Although at this point Lacan's recasting of Freud tended to go unmentioned by the Screen writers, the French psychoanalyst's work subsequently gained in prominence, especially with Heath's article "Anata Mo" (a discussion of Lacan's notion of the real in conjunction with Oshima's Death by Hanging) and the published translation of Oudart's "La Suture" with appended notes on the text by Heath. ${ }^{18}$

And yet, in contrast with the situation at Cahiers, psychoanalytic film theory was far from unanimously welcomed by the editors of Screen and was the cause of a rupture in its editorial board: in the Summer 1975 number, the editorial noted opposition within the journal's ranks to the "esoteric" nature of certain articles drawing on Freud and Lacan and expressed concern at their "lack of real engagement with the politico-cultural issues which should form the context of Screen's work." ${ }^{19}$ Later that year, these reservations were expanded upon in a statement signed by Edward Buscombe, Christine Gledhill, Alan Lovell and Christopher Williams, which bemoaned the "lack

15 See Ben Brewster and Colin MacCabe, "Editorial," Screen vol. 15 no. 1 (Spring 1974), pp. 4-10; Colin MacCabe, "Realism and the Cinema: Notes on Some Brechtian Theses," Screen vol. 15 no. 2 (Summer 1974), pp. 7-27; and Stephen Heath, "Lessons from Brecht," Screen vol. 15 no. 2 (Summer 1974), pp. 103-128. The Brecht special issue also included a text by Bernard Eisenschitz, "Who does the World Belong to? The Place of a Film," Screen vol. 15 no. 2 (Summer 1974), pp. 66-73. 16 Julia Lesage, "The Human Subject - You, He or Me? (Or, the Case of the Missing Penis)," Jump Cut no. 4 (November-December 1974), pp. 26-27. Repr. in Screen vol. 16 no. 2 (Summer 1975), pp. $77-83$.

17 Ben Brewster, Stephen Heath and Colin MacCabe, "Comment," Screen vol. 16 no. 2 (Summer 1975), pp. 83-9o, here p. 84 .

18 Stephen Heath, “Anata Mo," Screen vol. 17 no. 4 (Winter 1976-1977), pp. 49-66; Jean-Pierre Oudart, “Cinema and Suture," trans. Kari Hanet, Screen vol. 18 no. 4 (Winter 1977-1978), pp. 24-34; and Stephen Heath, "Notes on Suture," Screen vol. 18 no. 4 (Winter 1977-1978), pp. 48-76.

19 “Editorial," Screen vol. 16 no. 2 (Summer 1975), pp. 4-6, here p. 6. 
of any critical distance from psychoanalysis in Screen" and reproached texts by Heath, MacCabe and others for their supposed conceptual obscurity and inaccessibility. ${ }^{20}$ The tensions within the editorial board on this matter were never adequately resolved and led to the departure of the statement's four signatories in the summer of $1976 .{ }^{21}$

Although Screen's deployment of psychoanalytic concepts had mixed results, one area in which it was undeniably fecund on the theoretical level was in the fusion of psychoanalysis with feminist film theory carried out in Laura Mulvey's landmark article "Visual Pleasure and Narrative Cinema," which first appeared in the Autumn 1975 issue of the journal. Mulvey was not the first to make this conceptual maneuver or to draw on the ideas of Cahiers to do so: Pam Cook and Claire Johnston had earlier evoked Comolli/Narboni's call for an "oblique, symptomatic reading" of the discrepancies and fault lines in auteurist classical cinema to discuss the position of 'woman' as the locus of a dilemma for the patriarchal human order" in Raoul Walsh's œuvre..$^{22}$ But the explosive effect of her article was such that "Visual Pleasure and Narrative Cinema," with its argument that the mechanism of spectatorship in classical narrative cinema is decisively determined by a scopophilic "male gaze," is still considered one of the major texts in the field. While the psychoanalytically inflected articles of Cahiers are an evident precursor to Mulvey's text, particularly in her discussions of Sternberg's Morocco, it is when her attention turns to the role of voyeurism in Vertigo that Mulvey's debt to the journal is most apparent. But here the influence comes from an unexpected source: not any of the Cahiers writers of the Comolli/Narboni era but rather Jean Douchet's 1960 text "Hitch et son public," in which the right-leaning, resolutely cinephilic critic analyzes the film as a metaphor for the very functioning of the cinema. ${ }^{23}$ Indeed, while Mulvey concludes by asserting that women "cannot view the decline of the

20 Particular areas of censure centered on the notions of fetishism, the analogy of film spectatorship with the infant's mirror phase (as discussed by Metz in The Imaginary Signifier) and the pedagogically unprofitable assumption that the viewer of mainstream narrative cinema is an innately passive consumer of images. See Edward Buscombe, Christine Gledhill, Alan Lovell and Christopher Williams, "Statement: Psychoanalysis and Film," Screen vol. 16 no. 4 (Winter 1975), pp. 119-130, here p. 119.

21 See Edward Buscombe, Christine Gledhill, Alan Lovell and Christopher Williams, "Why We Have Resigned from the Board of Screen," Screen vol. 17 no. 2 (Summer 1976), pp. 106-109. 22 Pam Cook and Claire Johnston, "The Place of Woman in the Cinema of Raoul Walsh," in Philip Hardy (ed.), Raoul Walsh (London: BFI, 1974), pp. 92-109, here p. 109. The article was the source of a polemic between Alan Lovell, Colin MacCabe and Elizabeth Cowie in "Film Culture," Screen vol. 16 no. 1 (Spring 1975), pp. 128-141.

23 Jean Douchet, "Hitch et son public," Cahiers du cinéma no. 113 (November 1960), pp. 7-15. 
traditional film form with anything much more than sentimental regret," a certain ambivalent attitude towards classical cinema can be detected in her text, one that links it more closely with the Cahiers tradition than may be immediately apparent: while Hollywood films mobilize the male gaze, their best examples (Sternberg, Hitchcock) are also able to operate an internal critical analysis of the scopophilic mechanism at the heart of the cinematic apparatus. ${ }^{24}$

\section{Theoretical Flows and Countercurrents in the 1970s and 1980s}

Mulvey's article instigated a flurry of theoretical reflection in the second half of the 1970s and the 1980 s that combined a feminist outlook (often inspired by French thinkers such as Kristeva, Hélène Cixous and Luce Irigaray) with Freudian/Lacanian approaches to the cinema. Key figures in this tendency included Linda Williams, Teresa de Lauretis and Kaja Silverman, ${ }^{25}$ and it is probably the most striking example of the ideas developed by the Cahiers critics in the post-1968 period serving as the basis of a theoretical undertaking that was quite remote from their own. The "flow," therefore, of ideas from France to the UK and North America was a more complex process than that of a straightforward importation or transplantation into a new context and involved a significant degree of original thinking on the part of the latter figures. It must be reiterated, however, that there were distinct limitations to this transference: not only was it based on a very limited number of the vast corpus of texts produced by Cahiers during this period, there was also little cognizance of the evolution of the French journal in the years after 1973 (a period when many of its earlier positions were subject to extensive criticism), and the journal's more recent articles received meager attention. ${ }^{26}$ Moreover, the theoretical flow was a distinctly monodirectional affair: there is scant evidence of the Cahiers writers being in any way influenced by theoretical developments in Screen or other anglophone journals, which they were only

24 Mulvey, "Visual Pleasure and Narrative Cinema," p. 18. This ambivalence is curiously present in The Riddles of the Sphinx, made by Mulvey and Wollen, in the beginning of which the former can be seen leafing through a copy of the French film magazine Midi-minuit fantastique (which concentrated on série B and horror films).

25 Oudart's notion of the suture was of particular importance for this strand of film theory, and this relationship will thus be further discussed in Chapter 22.

26 One exception was Jean-Louis Comolli's “Un corps en trop" (Cahiers du cinéma no. 278, July 1977, pp. 5-16) which was published in English translation as "Historical Fiction: A Body Too Much," trans. Ben Brewster, Screen vol. 19 no. 2 (Summer 1978), pp. 41-53. 
dimly aware of in the first place. There were two major exceptions to this state of affairs, both of which arose through Cahiers writers taking part in conferences organized by sympathizers in the UK and the US, events which also revealed a significant degree of friction between their French and Anglo-American participants. In 1977, Serge Daney traveled to the Edinburgh Film Festival as an invited guest for a symposium organized by the Screen editors on the topic of "History/Production/Memory." In Daney's account, however, the event was marked by a series of discords and décalages between himself and his British interlocutors. Noting that the theoretical references of the conference participants centered on Althusser, Derrida and Lacan (but a Lacan that was, in Daney's view, "truncated, reduced to a ping-pong game between the imaginary and the symbolic, without the moment of the real"), he observed that the position of Cahiers was repeatedly brought into question: "It was vaguely recognized as having been the first to show a preoccupation with 'cinema-and-history' in its columns, but it was silently reproached for having moved away from an orthodox position [towards] a highly suspect spontaneism. ${ }^{27}$ For his part, Daney felt that the discussions at Edinburgh tended to neglect "the historical conditions in which this debate appeared, in the French far-left and in Cahiers in particular," with a narrow Althusserianism instead leading the symposium's participants to view this moment as "a pure struggle in theory." ${ }^{28}$ In the end, Daney concluded, the one thing that was forgotten during the event, as its title symptomatically revealed, was the cinema itself.

A similarly disharmonious tone marked the following year's conference on "The Cinematic Apparatus," held in Milwaukee and organized by Stephen Heath and Teresa de Lauretis, which was attended by a number of key figures from the nascent field of Anglo-American film studies (Peter Wollen, Mary Ann Doane, Dudley Andrew, Kristin Thompson, Maureen Turim, Laura Mulvey and Bill Nichols among them) as well as Christian Metz and Jean-Louis Comolli. The conference was already a source of controversy, as the editors of Jump Cut had waged a vocal campaign against its "elitist" and "sexist" organizational principles. ${ }^{29}$ Once the conference was underway, significant and sometimes acrimonious differences between Comolli's views and those of many of the other attendees also became apparent: a

27 Serge Daney, “Festival d'Edinbourg: Histoire/Production/Mémoire," Cahiers du cinéma no. 283 (December 1977), pp. 57-6o, here p. 57.

28 Ibid., pp. 57-58.

29 See B. Ruby Rich, Chuck Kleinhans and Julia Lesage, "Report on a conference not attended: The scalpel beneath the suture," Jump Cut no. 17 (April 1978), pp. 37-38. 
screening of his film La Cecilia in conjunction with the conference met with an unfavorable reception from the attendees, highly critical of its portrayal of women, while his paper "Machines of the Visible" (a series of extracts from "Technique et idéologie" alongside more recently composed passages) was subject to a feminist critique by Jacqueline Rose..$^{30}$ Most rancorous, however, was an exchange between Comolli and the structuralist/ materialist filmmaker and theorist Peter Gidal: Comolli's argument that even abstract, non-figurative films can produce spectatorial fascination and that avant-garde cinema may be less necessary in the 1970s than it was at a time when Hollywood's domination of cinematic form was more absolute met with a virulent response from Gidal, who exclaimed to his French counterpart "you must be blind" before comparing his remarks to "Radek's speech against James Joyce." ${ }^{11}$

If these exchanges marked moments of dissension within the ranks of those who identified with "apparatus theory" during the 1970s, then the following decade would be distinguished by a frontal attack on the entire movement, which would continue until well into the 199os. The offensive began with Noël Carroll's 74-page review for October of Heath's Questions of Cinema. Heath's anthology, completed in January 1980, can in retrospect be seen as a symbolic capstone of "1970s theory" in its Anglo-American guise..$^{32}$ Carroll's riposte, drawing chiefly on a logical positivist methodology, was relentless in its opprobrium and centered around the argument that the Screen contributor's theoretical model suffered at once from the "enfeebling $[\ldots .$.$] hyper-generality" of its overarching concepts of suture and subject-$ positioning and from "sacrific[ing] focus for detail" in its micro-descriptions of the film-viewing situation. ${ }^{33}$ This critique launched a debate with Heath in subsequent issues of October which, while forming one of the most vocal and detailed polemics between the theoretical tendencies these two scholars represented, often descended into petty personal bickering. ${ }^{34}$ The ideas sketched out by Carroll in these articles would form the basis of Mystifying Movies, his 1988 book-length take-down of apparatus theory's fusion of

30 See Jean-Louis Comolli, "Machines of the Visible," in Stephen Heath and Teresa de Lauretis (eds.), The Cinematic Apparatus (London: Macmillan Press, 1980), pp. 121-142; and Jacqueline Rose, "The Cinematic Apparatus: Problems in Current Theory," in Heath/de Lauretis (eds.), The Cinematic Apparatus, pp. 172-186.

31 Heath/de Lauretis (eds.), The Cinematic Apparatus, pp. 170-171.

32 Stephen Heath, Questions of Cinema (Bloomington: Indiana University Press, 1981).

33 Noël Carroll, "Address to the Heathen," October no. 23 (Winter 1982), pp. 89-163, here p. 163.

34 See Stephen Heath, "Le Père Noël," October no. 26 (Autumn 1983), pp. 63-115; Noël Carroll, "A Reply to Heath," October no. 27 (Winter 1983), pp. 81-102. 
psychoanalysis, semiotics and Marxist notions of ideology. ${ }^{35}$ At the same time, and in tandem with Carroll's work, David Bordwell was embarking on a similar undertaking, the arguments of which were most clearly expressed in his 1988 article "Historical Poetics of Cinema." Here, Carroll's positivist philosophical arsenal was joined by a "neoformalist" approach derived from early twentieth-century Slavic poetics. ${ }^{6}$

Both figures tended to view apparatus theory as a monolithic entity that dominated the academic "establishment" in film studies (if not the humanities more broadly), and they referred derisively to their polemical target as "The Theory," "Grand Theory," or, in Bordwell's coinage, "SLAB Theory" (the letters standing for Saussure-Lacan-Althusser-Barthes), a nomenclature that suggests a conceptual homogeneity and claim to universal validity that was never truly present in the original texts. The culmination of Bordwell and Carroll's dismantling of "1970s theory" came in the 1995 edited collection Post-Theory. Here, in addition to continuing their attacks on psychoanalytic and semiotic approaches to the cinema, they espoused the pursuit of "middle-level research" as an alternative practice to "Theory," one that would combine the collection of detailed empirical data with the development of modest, verifiable theoretical claims and which, in their eyes, had found a viable methodological model in the wave of "new" film history that had emerged in the 1980 s. $^{37}$

\section{“Technique et idéologie" and the New Film History Movement}

Bordwell's evocation of research into film history relates to another critique of the theoretical tradition derived from Cahiers that was issued from various quarters in the 1980s: that its discussion of the role of ideology in the cinema was largely ahistorical, essentializing "bourgeois ideology" and presenting it as an amorphous, eternal entity divorced from historical context. Here, the value of Comolli's "Technique et idéologie," in particular, came into question. Dudley Andrew, for instance, argued in Concepts in Film Theory that, "for all their concern to document the ideological underpinnings of the lens and its perspectival image," the Cahiers critics-and Comolli

35 Noël Carroll, Mystifying Movies (New York: Columbia University, 1988).

36 David Bordwell, "Historical Poetics of Cinema," Georgia State Literary Studies no. 3 (1989), pp. 369-398.

37 David Bordwell, "Film Studies and Grand Theory," in David Bordwell and Noël Carroll (eds.), Post-Theory: Reconstructing Film Studies (Madison: University of Wisconsin Press, 1995), pp. 3-36, here p. 27 . 
more particularly — "can be indicted for their own brand of idealism since they have essentially reified technology for all time." Andrew unfavorably compared their work with that of those American scholars who had "tried to show the complex interplay of historical context in the invention and use of new technology." 38 This argument was echoed by Bordwell, who, while accepting the value of Comolli's "emphasis upon the lag between technological possibility and extended use" and his "non-teleological model of change," criticized "Technique et idéologie" as "sweepingly reductive." For Bordwell, Comolli made "the concept of 'ideology' do too much work," assuming "that 'bourgeois ideology' rests in place for three centuries, from Caravaggio to Citizen Kane." In this context, he also reiterates Sartre's critique of "lazy' Marxists who replace 'real, perfectly defined groups' by vague collectivities such as 'bourgeois ideology.”39

This criticism is a curious one to make in light of the consistent emphasis placed by Comolli on the importance of charting the historical metamorphoses of the ideologies embedded in the cinema, his insistence on refusing an autonomous approach to film history and stressing the political and economic factors at work in the evolution of film form and technique, and his explicit concern with historiographic methods (and more particularly his adoption of the Althusserian model of "differential historical temporalities"). The success of his approach, and the validity of his findings, is certainly open to question. Indeed, given the enormous strides forward in our understanding of the early history of the cinema, it would be a tremendous surprise if Comolli's text were not empirically outdated in certain respects. But the notion that in "Technique et idéologie" Comolli sweepingly ignored the broader historical context of transformations occurring in film technology and eternalized the "ideological apparatus" of the cinema is one that does not withstand scrutiny. ${ }^{40}$

It is also not an argument made by any of the representatives of the "new film history" movement itself, who, in the wake of the 1978 FIAF congress at Brighton, sought to revisit and re-evaluate the accounts of early cinema provided by preceding generations of film historians (such as Ramsaye, Jacobs, Sadoul and Mitry) and who were often quite amenable to Comolli's vision of

38 Dudley Andrew, Concepts in Film Theory (Oxford: Oxford University Press, 1984), p. 16.

39 David Bordwell, Janet Staiger and Kristin Thompson, The Classical Hollywood Cinema: Film Style and Mode of Production to 1960 (New York: Columbia University Press, 1985), pp. 247, 249-250.

40 The translation history of Comolli's text is partly a factor in this distortion. The historical element in his discussion becomes more preponderant in the later parts of "Technique et idéologie," which long remained publicly inaccessible in English. 
film history. Robert Sklar has outlined the sharp fault line that dominated historical study of the cinema during this period, dividing the field between adherents of an Althusserian Marxist approach to the understanding of ideology and social change and those who remained within more traditional methods of historical research, with mutual hostility reigning between the two sides. ${ }^{41}$ And yet the main proponents of what has come to be known as the "post-Brighton" school of film history-Tom Gunning, Charles Musser and André Gaudreault, most notably_-all evince a significant debt to Comolli's text. The anti-teleological thrust of Gunning's notion of the "cinema of attractions," which opposed a conception of the early period of the cinema as the primitive form of a later state of perfection attained by the medium, finds a notable forerunner in Comolli's polemics against the "teleological" presentations of film history provided by Bazin, Mitry and others. ${ }^{42}$ In a similar vein, Musser has invoked Comolli when warning of the ideological pitfalls that can be encountered in the search for "first times" in accounts of the evolution of film techniques, although he also cautions against an approach that would veer too far in the other direction and "seek to forsake starting points entirely [or] offer the possibility of so many starting points that the notion of a beginning is not only diffused but ultimately avoided." ${ }^{43}$

It is Gaudreault, however, who has most unabashedly asserted the importance of "Technique et idéologie" for the new generation of film historians. In his recent text, Film and Attraction, the Quebecois scholar forcefully argues for the influence of the Cahiers critic. He insists that "Comolli's articles were one of the rare studies to give a thrashing to 'official history' at such an early date and in such a systematic and forceful manner" and that they formed "a user's manual for the scholars who were soon about to express an interest in the early days of cinema." ${ }^{\prime 4}$ Gaudreault even goes so far as to call the movement "post-Comolli criticism," avowing that its members "borrowed, consciously or not, from Comolli's shaking up of official history."45

41 Robert Sklar, "Oh! Althusser!: Historiography and the Rise of Cinema Studies," in Robert Sklar and Charles Musser (eds.), Resisting Images: Essays on Cinema and History (Philadelphia: Temple University Press, 1990), pp. 12-36.

42 Gunning has written amply on the "cinema of attractions," but the concept was first adumbrated in his "The Cinema of Attractions: Early Film, Its Spectator and the Avant-Garde," Wide Angle vol. 8 no. 3-4 (Fall 1986), pp. 63-70.

43 Charles Musser, The Emergence of Cinema: The American Screen to 1907 (New York: Scribner, 1990), p. 15 .

44 André Gaudreault, Film and Attraction: From Kinematography to Cinema, pp. 11, 16.

45 Ibid., pp. 12, 16. This esteem for the groundbreaking character of Comolli's work was no doubt a major motivation for Gaudreault to co-organize the "Impact of Technological Innovations on the Historiography and Theory of Cinema" conference in 2011, which brought together many of 
The repercussions of Comolli's text for the new film historians was, like the influence of Cahiers on Screen in the 1970s, largely a one-way affair: there has been little sign of Comolli theoretically engaging or personally collaborating with the major figures in this area of research. For a direct, individual link between the Cahiers of the post-1968 period and "post-Brighton" film historiography, we must therefore turn to another of the journal's alumni: Jacques Aumont. Aumont's position as a founding figure of film studies as an academic discipline in France, contemporaneous with its development in the English-speaking world, and his broader, decades-long project to theorize film aesthetics (discussed further in Chapter 19), have inevitably entailed a deep preoccupation with the early history of the cinema. Moreover, his ties with English-language academia were deepened with his editorship of the bilingual journal Iris in the 1980s, which published the work of French and North American scholars in equal measure. In this vein, a couple of projects stand out from among his large corpus of writings and activities. In August 1985, Aumont co-organized with André Gaudreault and Michel Marie a symposium at Cerisy on the topic "L'Histoire du cinéma: nouvelles approches." One of the first conferences - in France or anywhere - to specifically present the work of the "new film historians," the colloque's proceedings, including contributions by Gunning, Rick Altman, Paolo Cherchi Usai and Mitry, were published in book form in $1989 .{ }^{46}$ In addition, Aumont can also be credited with contributing to the revival of scholarly interest in the work of D.W. Griffith, the reconsideration of whose œuvre would-thanks also to the work of Gunning ${ }^{47}$ - become a major aspect of research into the early history of the cinema. In Aumont's contribution to Bellour's landmark edited collection Le Cinéma américain, "Griffith, le cadre, la figure," he argues that shot construction in Griffith's Biograph era works functions along strikingly different principles than later conventional film practice. In these films dating from 1908-1912, Griffith "does nothing to hide the white threads which sew the frames together: on the contrary, he makes much of them, flaunts them, puts a great deal of emphasis on them, marks them with a whole signifying apparatus"; as such, the pioneer of American cinema, for

the "original combatants" of the "technique and ideology" debates—including Comolli, Leblanc and Lebel—-to return to the issues raised 40 years earlier. See Daniel Fairfax, "Conference Report: The Impact of Technological Innovations on the Historiography and Theory of Cinema," Cinema Journal vol. 52 no. 1 (Fall 2012), pp. 127-131.

46 Jacques Aumont, André Gaudreault and Michel Marie (eds.), L'Histoire du cinéma: Nouvelles approches (Paris: Publications de la Sorbonne, 1989).

47 See Tom Gunning, D.W. Griffith \& The Origins of American Narrative Film (Chicago: University of Illinois Press, 1994). 
Aumont, remains resolutely outside the codes of continuity editing that would become the dominant practice in the classical Hollywood system. ${ }^{48}$

\section{The Legacy of Cahiers du cinéma and "Apparatus Theory" Today}

Bordwell and Carroll's attacks on "Grand Theory" left their opponents reeling and were accompanied by parallel undertakings such as Richard Allen's Projecting Illusion, which used a Wittgensteinien approach to challenge Althusserian and Lacanian ideas on the functioning of the cinematic apparatus. ${ }^{49}$ While contributors to Screen and other figures in the anglophone academy were the main targets of these strictures, it was inevitable that the Cahiers writers, and in particular their psychoanalytically oriented texts, should find themselves in the crosshairs. By the 1980s and 1990s, indeed, few could be found to champion this tendency. Many of the earlier proponents of "apparatus theory" had abandoned it as a conceptual paradigm, often embarking on turns to cultural studies or Deleuzian/Foucauldian approaches to film theory. Even defenders of its legacy, such as D.N. Rodowick, had to accept that "political modernism" had entered a "crisis" and sought to draw out the contradictions and shortcomings of the original theories, while hoping to salvage a kernel of theoretical validity from amidst the conceptual wreckage.

Rodowick's was not the first retrospective account of this theoretical tradition. As precursors to The Crisis of Political Modernism we can count, with a focus on the French context, Sylvia Harvey's superb account of the political climate in which Cahiers and Cinéthique developed their theoretical perspectives (May '68 and Film Culture) and George Lellis' more prosaic overview of the relationship between Brechtian artistic practices and the critical work of Cahiers (Bertolt Brecht, Cahiers du Cinéma and Contemporary Film Theory), while Dana Polan also provides a broad summary of this tendency in film theory, albeit with less focus on Cahiers, in his study The Political Language of Film and the Avant-Garde..$^{50}$ But Rodowick was the

48 Jacques Aumont, "Griffith, le cadre, la figure," in Raymond Bellour (ed.), Le Cinéma américain vol. I(Paris: Flammarion, 1980), pp. 51-67, here pp. 59-6o. Translated as "Griffith: The Frame, the Figure," in Early Cinema: Space, Frame, Narrative, ed. Thomas Elsaesser (London: BFI Publishing, 1990), pp. 348-359, here p. 353 .

49 Richard Allen, Projecting Illusion: Film Spectatorship and the Impression of Reality (Cambridge: Cambridge University Press, 1995).

50 See Sylvia Harvey, May'68 and Film Culture; George Lellis, Bertolt Brecht, Cahiers du Cinéma and Contemporary Film Theory; and Dana Polan, The Political Language of Film and the AvantGarde (Ann Arbor: UMI Research Press, 1985). 
first to categorically state what had elsewhere, by the late 1980s, become a generalized sentiment in the field: that the tendency of "political modernism," "apparatus theory," "Screen theory" or "1970s theory" was in a state of crisis. In the preface to the second edition of his monograph, Rodowick memorably stated that "the 1970s, or what I call the era of political modernism, is often treated with an equal mixture of pride and embarrassment"; moreover, from the perspective of 1994, he argued that the "formalism and extravagant political claims" of this period appear "a bit passé. ${ }^{11}$ Nonetheless, he points to the contradictory attitude towards this foundational moment in the field, noting that "film studies today tends retroactively both to pose and to deny its historical continuities with the 1970s," and he asserts that "the era of political modernism is still with us in many ways." ${ }^{2}$ The acuity of Rodowick's study is indisputable, and the scope of his framework is also impressive, taking in the gamut of the theoretical, political and formal concerns that were at the core of political modernism, a term that, although not coined by Rodowick, his book has served to popularize. 53 However, The Crisis of Political Modernism often has a tendency to elide the role of Cahiers and Cinéthique in acting as a conduit between the "French theory" of Tel Quel, Derrida, Lacan and Althusser and its introduction into Anglo-American film studies. Oudart, for instance, is curiously absent from Rodowick's discussion of suture, which passes directly from Jacques-Alain Miller to Stephen Heath, despite the fact that Heath is explicitly indebted to the Cahiers critic. ${ }^{54}$ Moreover, when Cahiers is discussed, Rodowick almost exclusively turns to the "Cinéma/idéologie/critique" editorial, leaving the vast corpus of other writings in the journal largely untouched.

Ironically, at the same time that Rodowick was writing, the number of articles from Cahiers' post-1968 period available in English rapidly expanded with the 1990 publication of the third volume of the BFI's selection of Cahiers articles, focusing on the years 1969-1972. In his introduction to the volume, Nick Browne lucidly defends the Cahiers project of this period and expands the terrain on which the journal's theory should be judged to cover lesser known texts such as Oudart's "Jeux de mots, jeux de maitre," Oudart, Narboni and Comolli's "Lectures de Jancsó: hier et aujord'hui" and Daney and Oudart's "Le Nom-de-l'Auteur (à propos de la 'place' de Mort à Venise)." ${ }^{55}$ This effort vol. 23 no. 1 (May-June 1982), pp. 45-59.

54 Ibid., pp. 193-197.

Ibid., pp. vii-viii.

Rodowick, The Crisis of Political Modernism, p. vii.

The term first appeared in Sylvia Harvey, "Whose Brecht? Memories for the Eighties," Screen

See Browne, "Introduction: The Politics of Representation." 
was followed a decade later with the fourth and final volume in the series covering the period 1973-1978. While these anthologies have been invaluable in providing greater access for English readers to previously unavailable material, the ensuing decades have seen few efforts to resuscitate this work for a contemporary context. One of the rare exceptions has been Martin Jay's endeavor, in Downcast Eyes, to situate the post-1968 Cahiers within a broader critique of "ocularcentric" thought in French critical theory, with Daney's "Sur Salador" and Comolli's "Machines of the Visible" both discussed at length in this framework. ${ }^{6}$

The key Cahiers texts, such as "Cinéma/idéologie/critique," "Technique et idéologie" and "Young Mr. Lincoln de John Ford," have, of course, retained their canonical status within the discipline and still feature frequently in course syllabi and film theory anthologies. But they largely remain in a frozen state, read as documents of their time rather than being subject to productive re-readings or new lines of research. Indeed, when Rodowick returns to discussing Cahiers' critical legacy, he even more definitively associates them with the past tense of a remote historical era: if in 1988 he invoked the "crisis" of political modernism, he now speaks of an "elegy" for theory itself. ${ }^{57}$ Against such a mournful outlook consigning this work to a distant, outmoded past, I contend not only that a rigorous yet creative exegesis of the original Cahiers texts can hold valuable lessons for the field of film studies in the contemporary era but also that the most profitable avenue for this enterprise is to turn to the vast corpus of writing and filmmaking produced by the Cahiers critics themselves, whether during their time at the journal or in other outlets and media in the four decades since the landmark articles of the 1969-1972 period that have been discussed so far. It is this task that will occupy the following parts of this book.

\section{Works Cited}

Richard Allen, Projecting Illusion: Film Spectatorship and the Impression of Reality (Cambridge: Cambridge University Press, 1995).

Dudley Andrew, Concepts in Film Theory (Oxford: Oxford University Press, 1984). Jacques Aumont, "Griffith, le cadre, la figure," in Raymond Bellour (ed.), Le Cinéma américain vol. I (Paris: Flammarion, 1980), pp. 51-67. Translated as "Griffith:

56 Martin Jay, Downcast Eyes: The Denigration of Vision in Twentieth-Century French Thought (Berkeley: University of California Press, 1995), pp. 464-492.

57 See Rodowick, Elegy for Theory. 
The Frame, the Figure," in Early Cinema: Space, Frame, Narrative, ed. Thomas Elsaesser (London: BFI Publishing, 1990), pp. 348-359.

—, André Gaudreault and Michel Marie (eds.), L'Histoire du cinéma: Nouvelles approches (Paris: Publications de la Sorbonne, 1989).

David Bordwell, "Historical Poetics of Cinema," Georgia State Literary Studies no. 3 (1989), pp. 369-398.

—, "Film Studies and Grand Theory," in David Bordwell and Noël Carroll (eds.), Post-Theory: Reconstructing Film Studies (Madison: University of Wisconsin Press, 1995), pp. 3-36.

- Janet Staiger and Kristin Thompson, The Classical Hollywood Cinema: Film Style and Mode of Production to 196o (New York: Columbia University Press, 1985).

Ben Brewster, "Structuralism in Film Criticism," Screen vol. 12 no. 1 (Spring 1971), pp. 49-58.

—, and Colin MacCabe, "Editorial," Screen vol. 15 no. 1 (Spring 1974), pp. 4-10.

—, Stephen Heath and Colin MacCabe, "Comment," Screen vol. 16 no. 2 (Summer 1975), pp. 83-9o.

Nick Browne, "Introduction: The Politics of Representation: Cahiers du Cinéma 1969-1972," in idem. (ed.), Cahiers du Cinéma vol. III: 1969-1972 The Politics of Representation (London: Routledge, 1990), pp. 1-20.

Edward Buscombe, Christine Gledhill, Alan Lovell and Christopher Williams, "Statement: Psychoanalysis and Film," Screen vol. 16 no. 4 (Winter 1975), pp. 119-13o.

—, "Why We Have Resigned from the Board of Screen," Screen vol. 17 no. 2 (Summer 1976), pp. 106-109.

Noël Carroll, "Address to the Heathen," October no. 23 (Winter 1982), pp. 89-163.

—, "A Reply to Heath," October no. 27 (Winter 1983), pp. 81-102.

—, Mystifying Movies (New York: Columbia University, 1988).

Jean-Louis Comolli, "Technique and Ideology: Camera, Perspective, Depth of Field," trans. Diana Matias, Film Reader no. 2 (1977), pp. 128-140.

—, "Un corps en trop," Cahiers du cinéma, no. 278, July 1977, pp. 5-16. Translated as "Historical Fiction: A Body Too Much," trans. Ben Brewster, Screen vol. 19 no. 2 (Summer 1978), pp. 41-53.

—., "Machines of the Visible," in Stephen Heath and Teresa de Lauretis (eds.), The Cinematic Apparatus (London: Macmillan Press, 1980), pp. 121-142.

Jean-Luc Comolli and Paul Narboni [sic], "Cinema/Ideology/Criticism," trans. Susan Bennett, Screen vol. 12 no. 1 (Spring 1971), pp. 27-36.

Pam Cook and Claire Johnston, "The Place of Woman in the Cinema of Raoul Walsh," in Philip Hardy (ed.), Raoul Walsh (London: BFI, 1974), pp. 92-109.

Serge Daney, "Festival d'Edinbourg: Histoire/Production/Mémoire," Cahiers du cinéma no. 283 (December 1977), pp. 57-60.

Jean Douchet, "Hitch et son public," Cahiers du cinéma no. 113 (November 1960), pp. 7-15. 
Bernard Eisenschitz, "Who does the World Belong to? The Place of a Film," Screen vol. 15 no. 2 (Summer 1974), pp. 66-73.

Daniel Fairfax, "Conference Report: The Impact of Technological Innovations on the Historiography and Theory of Cinema," Cinema Journal vol. 52 no. 1 (Fall 2012), pp. 127-131.

Simon Field (with Peter Sainsbury), "Présentation," in Nicole Brenez and Michael Witt (eds.),Jean-Luc Godard:Documents (Paris: Centre Pompidou, 2006), p. 144. André Gaudreault, Film and Attraction: From Kinematography to Cinema, trans. Timothy Barnard (Urbana: University of Illinois Press, 2011).

Tom Gunning, "The Cinema of Attractions: Early Film, Its Spectator and the AvantGarde," Wide Angle vol. 8 no. 3-4 (Fall 1986), pp. 63-70.

—, D.W. Griffith \& The Origins of American Narrative Film (Chicago: University of Illinois Press, 1994).

William Guynn, "The Political Program of Cahiers du cinéma, 1969-1977," Jump Cut no. 17 (April 1978), pp. 32-35.

Sylvia Harvey, May'68 and Film Culture (London: BFI, 1980).

—, "Whose Brecht? Memories for the Eighties," Screen vol. 23 no. 1 (May/June 1982), pp. $45-59$.

Stephen Heath, "Lessons from Brecht," Screen vol. 15 no. 2 (Summer 1974), pp. 103-128.

_ , "Anata Mo," Screen vol. 17 no. 4 (Winter 1976-1977), pp. 49-66.

—, "Notes on Suture," Screen vol. 18 no. 4 (Winter 1977-1978), pp. 48-76.

-, Questions of Cinema (Bloomington: Indian University Press, 1981).

—, "Le Père Noël," October no. 26 (Autumn 1983), pp. 63-115.

Martin Jay, Downcast Eyes: The Denigration of Vision in Twentieth-Century French Thought (Berkeley: University of California Press, 1995).

Claire Johnston, "Film Journals: Britain and France," Screen vol. 12 no. 1 (Spring 1971), pp. 39-48.

Chuck Kleinhans, “Twelve Frames per Second," Jump Cut no. 17 (April 1978), p. 36. George Lellis, Bertolt Brecht, Cahiers du Cinéma and Contemporary Film Theory (Ann Arbor: UMI Research Press, 1982).

Julia Lesage, "The Human Subject - You, He or Me? (Or, the Case of the Missing Penis), Jump Cut no. 4 (November-December 1974), pp. 26-27. Repr. in Screen vol. 16 no. 2 (Summer 1975), pp. 77-83.

Alan Lovell, Colin MacCabe and Elizabeth Cowie in "Film Culture," Screen vol. 16 no. 1 (Spring 1975), pp. 128-141.

Colin MacCabe, "Realism and the Cinema: Notes on Some Brechtian Theses," Screen vol. 15 no. 2 (Summer 1974), pp. 7-27.

-, "The Politics of Separation (on Deux ou trois choses que je sais d'elle and Tout va bien)," Screen vol. 16 no. 4 (Winter 1975), pp. 46-61.

—, "Principles of Realism and Pleasure, Screen vol. 17 no. 3 (Autumn 1976), pp. 7-27. 
—, Tracking the Signifier: Theoretical Essays: Film, Linguistics, Literature (Minneapolis: University of Minnesota Press, 1986).

Laura Mulvey, "Visual Pleasure and Narrative Cinema," Screen vol. 16 no. 3 (Autumn 1975), pp. 6-18.

Charles Musser, The Emergence of Cinema: The American Screen to 1907 (New York: Scribner, 1990).

Jean-Pierre Oudart, "Cinema and Suture," trans. Kari Hanet, Screen vol. 18 no. 4 (Winter 1977-1978), pp. 24-34.

Dana Polan, The Political Language of Film and the Avant-Garde (Ann Arbor: UMI Research Press, 1985).

La Rédaction, "Réponses à Politique Hebdo," Cahiers du cinéma no. 229 (MayJune 1971), pp. 61-64.

B. Ruby Rich, Chuck Kleinhans and Julia Lesage, "Report on a conference not attended: The scalpel beneath the suture," Jump Cut no. 17 (April 1978), pp. 37-38.

D.N. Rodowick, The Crisis of Political Modernism, $2^{\text {nd }}$ ed. (Berkeley: University of California Press, 1994),

—, Elegy for Theory (Cambridge, MA: Harvard University Press, 2014).

Jacqueline Rose, "The Cinematic Apparatus: Problems in Current Theory," in Stephen Heath and Teresa de Lauretis (eds.), The Cinematic Apparatus (London: Macmillan Press, 1980), pp. 172-186.

Philip Rosen, "The Concept of Ideology and Contemporary Film Criticism," PhD dissertation, University of Iowa, 1978.

[Screen], "Editorial," Screen vol. 16 no. 2 (Summer 1975), pp. 4-6.

Robert Sklar, "Oh! Althusser!: Historiography and the Rise of Cinema Studies," in Robert Sklar and Charles Musser (eds.), Resisting Images: Essays on Cinema and History (Philadelphia: Temple University Press, 1990), pp. 12-36.

Christopher Williams, "Bazin on Neo-Realism," Screen vol. 15 no. 1 (Spring 1974), pp. 61-68.

Peter Wollen, “'Ontology' and 'Materialism' in Film,” Screen vol. 17 no. 1 (Spring 1976), pp. 7-25. 